\title{
Differentiation of Herpes Simplex Virus Types 1 and 2 by Plaque Appearances on Semicontinuous Rabbit Lens Epithelial Cells in the Clinical Laboratory
}

\author{
Shigehiro SATO, Hideo KANEKI, Junichi SHIRAI, Kiyomi TAKAHASHI \\ and Rinji KAWANA \\ Department of Bacteriology, School of Medicine, Iwate Medical University \\ (Received: January 11, 1993) \\ (Accepted: March 17, 1993) \\ Key words: rabbit lens epithelial cells (RLE), herpes simplex virus type 1 and 2 \\ (HSV1 \& 2), plaque differentiation, clinical laboratory
}

\begin{abstract}
Herpes simplex virus type 1 (HSV1) and type 2 (HSV2) were differentiated on the basis of different plaque appearance on semicontinuous rabbit lens epithelial (RLE) cells. Plaques produced by HSV1 strains were small; the mean diameter was $1.29 \pm 0.37 \mathrm{~mm} 3$ days after inoculation. HSV2 strains produced large and small plaques, with the ratio of large to small about 20:1. The mean diameters of the large and the small plaques of HSV2 were $3.34 \pm 0.56 \mathrm{~mm}$ and $0.97 \pm 0.31 \mathrm{~mm}$ respectively 3 days after inoculation. The clones from the large plaques consistently produced large and small plaques and the small-plaque clones produced only small plaques. Round cells plus heterokaryotes were characteristic of the CPE of HSV1. Large plaques of HSV2 were produced by a large membranous syncytium that was liable to lyse. Small round cells were characteristic of the $\mathrm{CPE}$ of the small-plaque clones of HSV2. Glycoprotein C-negative $\left(\mathrm{gC}^{-}\right)$strains produced intermediate-sized plaques and a few pin point ones that consisted of membranous syncytia and round cells, respectively. Except for the HF strain (a reference strain of HSV1 producing a membranous syncytium on RLE cells), the result of the differentiation of HSV1 (179 strains) and HSV2 (40 strains) with the RLE plaque assay system was consistent with that of Syva's monoclonal antibody assay system and the restriction endonuclease digestion method.
\end{abstract}

\section{Introduction}

Difference in plaque-forming ability or plaque appearance between herpes simplex virus type 1 (HSV1) and type 2 (HSV2) had been studied in various cell culture systems ${ }^{1,2,7,12,13,15)}$, and are considered to be a biological marker distinguishing one from the other. Especially, primary chick emblryonic fibroblasts (CEF) are known to have unique characteristics for identifing HSV1 and HSV2. Most HSV1 isolates produce no plaques or small plaques on CEF. In contrast, large plaques are formed on CEF by HSV2 strains from the first passage of the virus ${ }^{2,7,12}$. CEF culture systems accompanied by other kinds of cell cultures were used to distinguish HSV1 from HSV2 in a clinical laboratory ${ }^{14)}$ or to select temperature-sensitive mutants for the study of pathogenicity in guinea pigs ${ }^{1}$.

Three morphologically distinct classes of plaques were seen on primary rabbit kidney (RK) cells ${ }^{15)}$ which are a more sensitive host for HSV1 strains than CEF are ${ }^{2}$. HSV2 strains produce plaques with sharp and abrupt edges on RK cells and HSV1 strains produce plaques either with much less distinct edges or

\footnotetext{
別刷請求先：（宁020）盛岡市内丸19-1 岩手医科大学細菌学教室 佐藤 成大
} 
syncitial in nature ${ }^{15)}$. Differentiation of each type of HSV strain by the appearance of plaques on the RK cells agreed with other criteria for the virus obtained by neutralization tests, by pock sizes on the chorioallantoic membrane of the chick embryo and by stability of thymidine kinase activity ${ }^{15}$.

According to Munk and Ludwigis), clones isolated from large plaques of genital strains consistently produced both large and small plaques; clones from small plaques of these strains produced only small plaques. They thought that this observation was characteristic of HSV2 strains. We confirmed this finding more definitively with the RLE plaque assay system. Large and small plaques of HSV2 were produced by a quite different cytopathic effect (CPE). The large plaques were produced by a membranous syncytium and the small ones consisted of round cells with no syncytium. The same observation was made with all the HSV2 strains studied here.

Semicontinuous RLE cell cultures were prepared for the study of rubella virus in our laboratory ${ }^{21)}$. We found unique characteristics of RLE cells in which HSV1 and HSV2 isolates were clearly distinguished from one another by their different plaque sizes. Difference in plaque sizes between HSV1 and HSV2 was clear at all points of subculture up to 90 passages. Differentiation of HSV1 and HSV2 by plaque appearance was satisfactory when it was compared with Syva's monoclonal antibody typing system ${ }^{11)}$ and with the restriction endonuclease digestion method ${ }^{18)}$. We report here a simple plaque assay system which is suitable for identifing HSV1 and HSV2 isolates in the clinical laboratory.

\section{Materials and Methods}

Preparation of the RLE cells:

RLE cells were prepared in our laboratory as described previously ${ }^{19)}$ with slight modification. The bulbus oculi was taken from a New Zealand white rabbit just after it was sacrificed by intravenous anesthesia. The lens was obtained aseptically and a sheet of the anterior capsule was carefully removed from the corpus of the lens with surgical forceps and scissors. The epithelial side of the capsule was then placed on the bottom of a $25-\mathrm{cm}^{2}$ Falcon plastic flask. The capsule was covered with a few drops of Eagle's minimum essential medium (MEM) supplemented with $20 \%$ fetal bovine serum until the epithelial cells started to grow. Medium of the same composition was continuously added until the cells became confluent. The culture was placed in a $5 \% \mathrm{CO}_{2}$ environment at $37^{\circ} \mathrm{C}$. After the 15 th splitting of the culture, the cells were grown and maintained with Eagle's MEM supplemented with $10 \%$ or $5 \%$ fetal bovine serum, respectively. No antibiotics were added to the culture throughout this study.

Growth curve of the RLE cells:

Growth characteristics of the RLE cells were studied at the 30th subculture. The cells were plated at $2.5 \times 105 / \mathrm{ml}$ in $25-\mathrm{cm}^{2}$ Falcon plastic flasks and the cells were counted daily.

Karyotype analysis:

The chromosome number of the RLE cells was determined at the 36th and 61st subcultures by the method previously described ${ }^{3)}$. A semiconfluent culture was treated with colchicine $(0.25 \mu \mathrm{g} / \mathrm{ml})$ for $2 \mathrm{hr}$, then treated with $0.075 \mathrm{M} \mathrm{KCl}$ and fixed with methylalcohol and glacial acetic acid (4:1). The cells were spread on a glass slide and stained with Giemsa stain. The chromosomes were counted under a light microscope.

Virus:

One hundred seventy-nine HSV1 and $40 \mathrm{HSV} 2$ strains were used for this study. One hundred twentynine HSV1 and $22 \mathrm{HSV} 2$ strains were isolated from clinical specimens in our laboratory. A total of $14 \mathrm{HSV} 1$ and 13 HSV2 isolates were kindly provided by several institutions in Japan: Dr. M. Niimura, Department of Dermatology, Jikei Medical School, Dr. T. Kawana, Department of Gynecology, Tokyo University, School of Medicine, Dr. R. Mori, Department of Virology, Kyushyu University, and Dr. T. Kurata, Department of 
Pathology, Institute of Medical Science, Tokyo University. Also, 32 HSV1 and 4 HSV2 isolates were kindly supplied by Dr. D.T. Hatzlet, Kenya Medical Research Institute, Nairobi, Kenya. Three glycoprotein C-negative $\left(\mathrm{gC}^{-}\right) \mathrm{HSV} 1$ strains consecutively isolated from a patient with herpetic keratitis were kindly provided by Dr. R. Mori, Kyushyu University. Reference strains HF (HSV1) and UW268 (HSV2) were kindly provided by Dr. K. Yoshino, Department of Virology, Tokyo University.

Cells:

Three continuous cell lines, HeLa, Vero, L132, and one semicontinuous cell line of human embryonic lung fibroblasts (HELF) were prepared in glass culture tubes to isolate HSV from various clinical specimens. The continuous cell lines were grown in Eagle's MEM supplemented with $10 \%$ fetal bovine serum, 100 units of penicillin per $\mathrm{ml}$, and $50 \mu \mathrm{g}$ of streptomycin per ml. The cells were maintained with occasional changes of maintenance medium consisting of Eagle's MEM and 2\% fetal bovine serum.

Typing of HSV1 and HSV2:

The immunofluorescent antibody technique using monoclonal antibodies (Syva Micro Trak HSV1/HSV2 Direct specimen Identification/Typing Test) ${ }^{11)}$ and the restriction endonuclease digestion method $^{18)}$ are described elsewhere. The monoclonal antibody assay was perfomed for all HSV strains studied this time. Thirty-nine HSV1 and 9 HSV2 strains were analyzed in our laboratory by the restriction endonuclease digestion method using Bam HI, kpn I and Sal I. Bgl II was occasionally used instead of Sal I. Thirty-two HSV1 isolates from Kenya were analyzed in other laboratory ${ }^{18)}$. Three gC-negative strains were analyzed and the results were published ${ }^{4,8)}$ before they were supplied.

Plaque assay:

Most of the HSV straines had not been passaged through the RLE cell cultures before inoculation. The number of passages of isolates through cell cultures was limited to as few as possible, usually 2 to 4 times, before plaque assay was performed, because greater heterogeneity of plaque sizes seemed to be encountered after extensive passage than those produced by the imitial preparations ${ }^{20)}$. HSV isolates were inoculated onto confluent RLE cell cultures $\left(1.3 \times 10^{6} / 25 \mathrm{~cm}^{2}\right.$ Nunc flask) and adsorbed for $60 \mathrm{~min}$ at $37^{\circ} \mathrm{C}$. The inoculum was then removed and the cells were covered with overlay medium consisting of phenol red-free Eagle's MEM containing $1 \%$ methylcellulose and $5 \%$ fetal bovine serum. The cultures were incubated at $37^{\circ} \mathrm{C}$ in a $5 \% \mathrm{CO}_{2}$ environment for 2 to 3 days. The plaques were observed after staining of the cells with $0.2 \%$ gentian violet dissolved in $10 \%$ buffered formalin.

$\mathrm{CPE}$ :

CPE of the HSV strains in the RLE plaque assay was observed before staining. The time required for CPE to appear in the rotation cell culture system was compared with that in RLE, HELF, RD and Vero cells by using limited dilution of each type isolate prepared in Vero cell cultures.

Growth characteristics of HSV1 and 2 on RLE cells:

Single-step growth curves of HSV1 and 2 on the 75th subculture of RLE cells were prepared. One of each of the clinical strains of HSV1 and 2 was inoculated at a multiplicity of infection of 3.0 onto monolayers of RLE cells $\left(8.8 \times 10^{4}\right.$ cells $)$ prepared in long-necked Leighton tubes. The virus was adsorbed for $60 \mathrm{~min}$ and then the cells were washed twice with Engle's MEM. Two cultures were harvested at each time point starting with $2.5 \mathrm{hr}$ and ending at the $46 \mathrm{th} \mathrm{hr}$ after inoculation. The cultures were kept at $-70^{\circ} \mathrm{C}$ until titration was performed. The cultures were subjected to freezing and thawing three times and the supernatant was recovered after centrifugation. The infectious titer of each time point was determined with the RLE plaque assay system.

Sensitivity of RLE cells for titration of HSV:

Infectious titers of five different isolates each of HSV1 and 2 obtained by RLE and Vero cell cultures were compared. Original virus preparations for both types of strains were made with Vero cell cultures. 
Susceptibility of RLE cells to other viruses:

Susceptibility of the RLE cells to enterovirus, rhinovirus, adenovirus, varicella-zoster virus (VZV) and cytomegalovirus (CMV) were studied. The RLE cell cultures that received about $100 \mathrm{TCID}_{50} / 0.2 \mathrm{ml}$ with the counterpart of the susceptible cells were titrated for virus growth with the same susceptible cell cultures used for titration.

\section{Results}

Characteristics of the RLE cells:

The RLE cells have been maintained up to 90 subcultures with a 1:4 split ratio for 3 years. Their epithelial-like nature has been maintained throughout all the passages (Fig. 1a). During the growth phase starting $24 \mathrm{hr}$ after plating of the cells, it took 1.5 days for the cells to double in number (Fig. 2). The culture showed contact inhibition at confluence. The growth curve obtained here showed agreement with the one reported previously ${ }^{19}$. From the spectrum of chromosome numbers obtained from the 39 th and 61 st

Fig. 1 (a) Monolayer of RLE cells at the 45th passage under low magnification (phase contrast microscopy). (b) Typical CPE of an HSV1 isolate consisting of syncytia and round cells $20 \mathrm{hr}$ after inoculation. (c) CPE of a syncytium-producing HSV2 (strain UW-268) clone making large plaques $16 \mathrm{hr}$ after inoculation. (d) CPE of a non syncytium-producing HSV2 (UW-268) clone making small plaques $16 \mathrm{hr}$ after inoculation. (e) Advanced CPE of non-syncytium producing HSV2 (UW-268) clones characterized by bead-like single round cells, $48 \mathrm{hr}$ after inoculation. (f) Syncytium produced by strain HF (HSV1) $14 \mathrm{hr}$ after inoculation, which are not apt to be lysed even after becoming much larger. (g) CPE of a syncytium-producing clone of HSV1 isolate (strain $\mathrm{gC}^{-}$) $18 \mathrm{hr}$ after inoculation. (h) Less syncytium was seen with small-plaque producing clone of the $\mathrm{gC}^{-}$strain $18 \mathrm{hr}$ after inoculation.

(a)

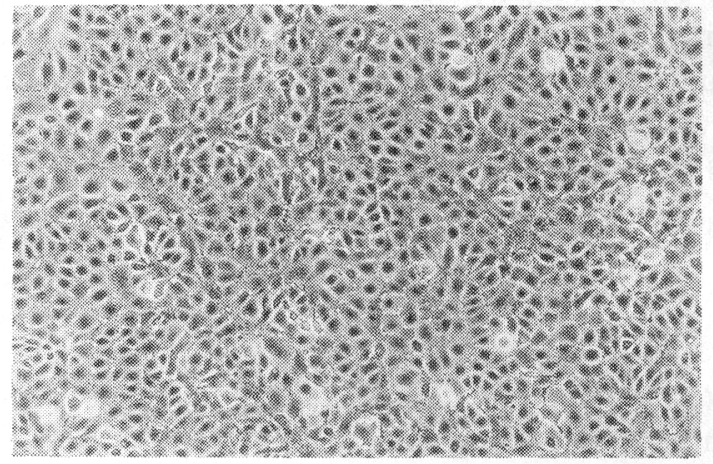

(c)

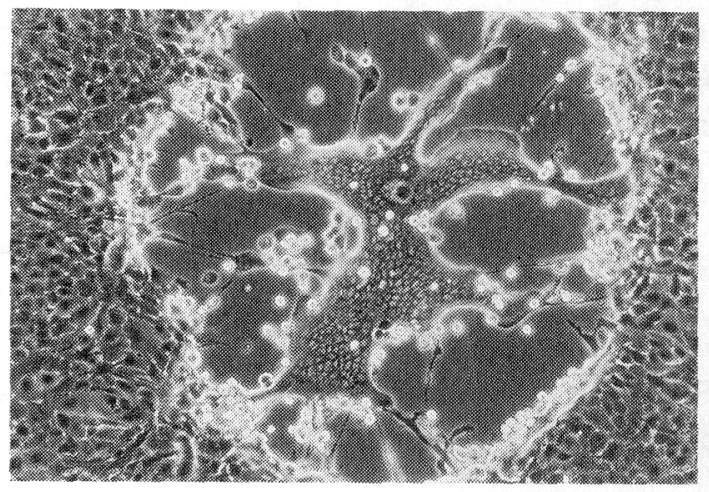

(b)

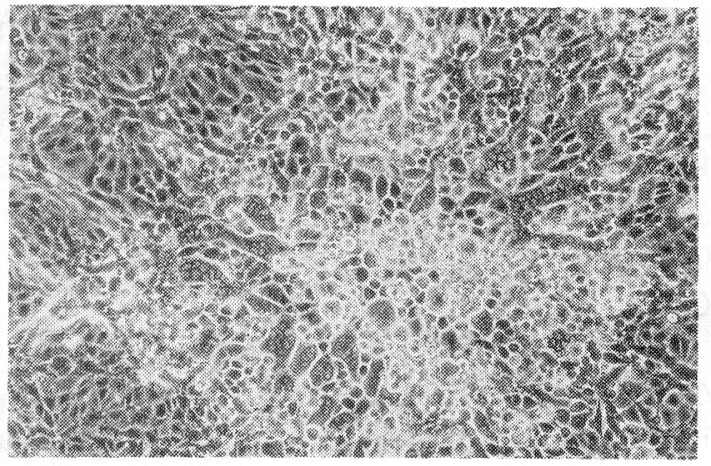

(d)

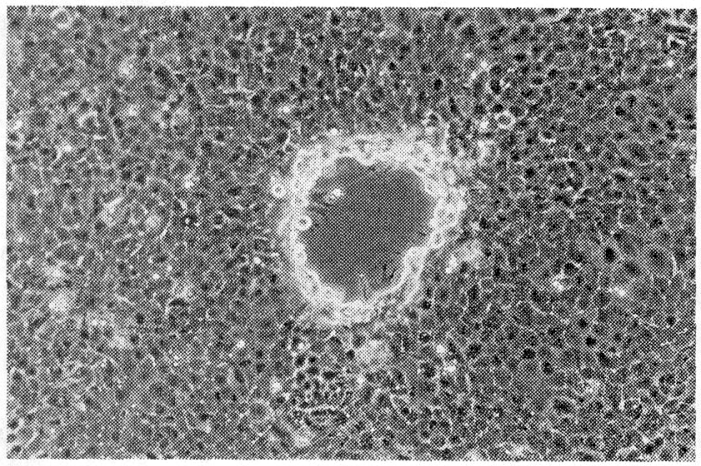


(e)

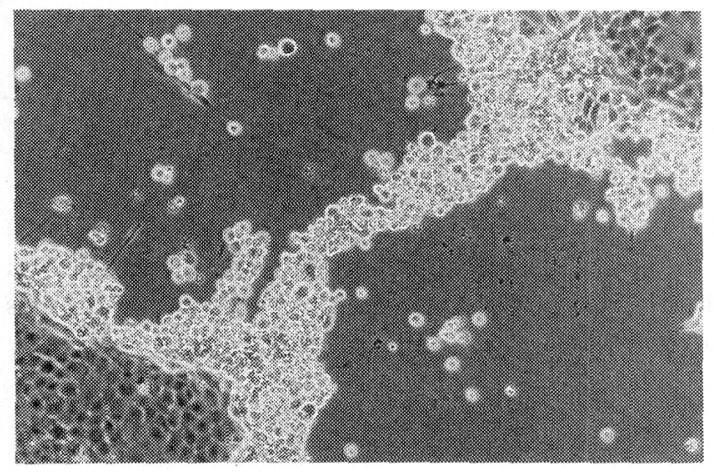

(g)
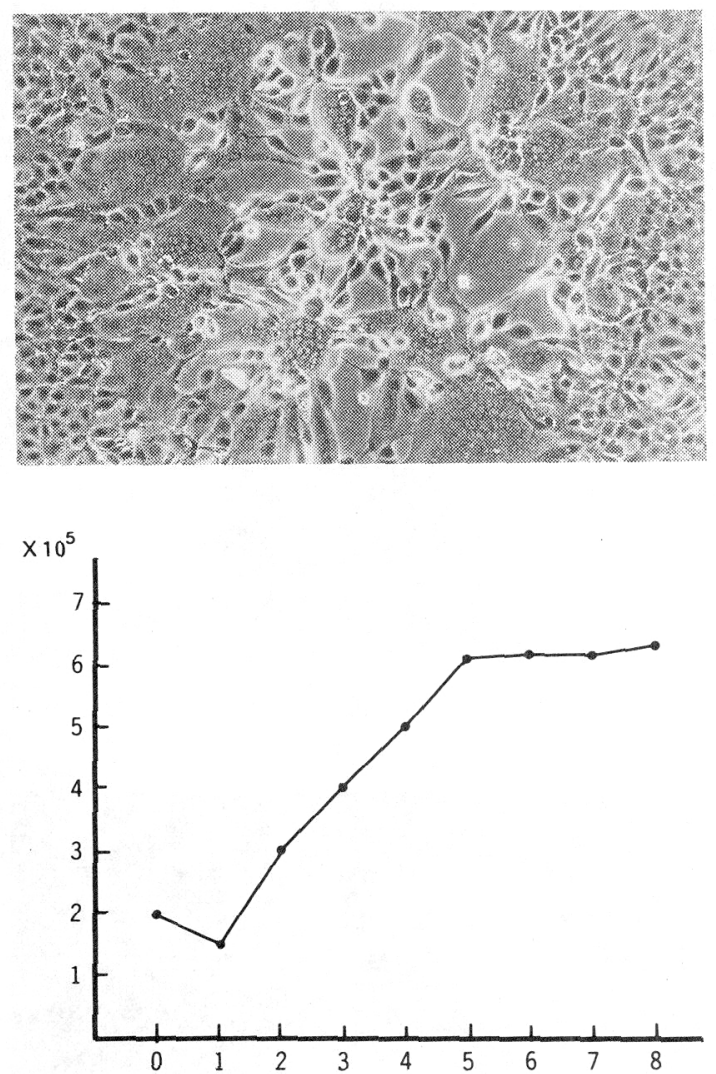

(f)

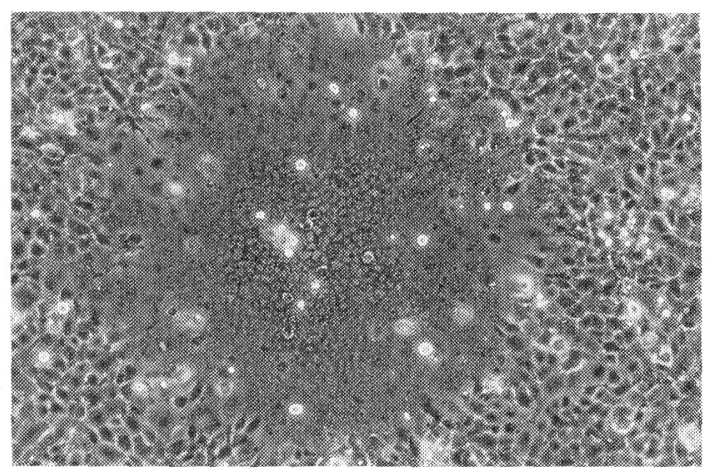

(h)

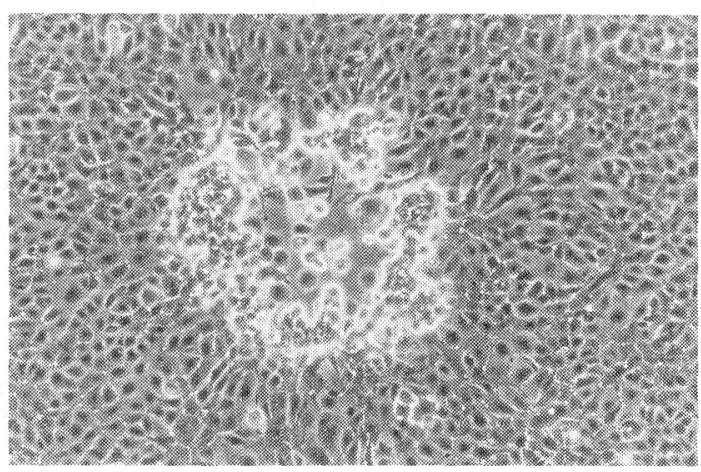

Fig. 2 Growth curve of RLE cells. Cells were plated at a density of $2.5 \times 10^{5} / \mathrm{ml}$ in $25-\mathrm{cm}^{2}$ Falcon plastic flasks and the cells were counted daily.

Table 1

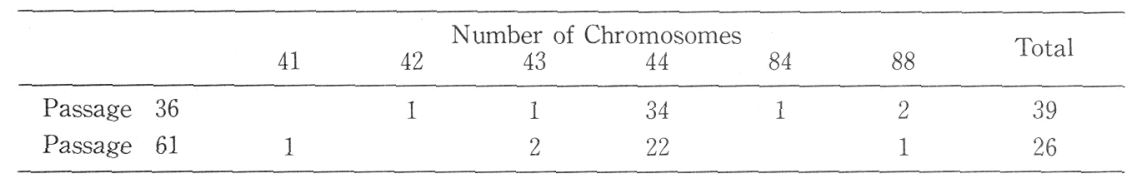


subcultures (Table 1), the RLE cells were considered to have 44 chromosomes, which is the diploid number of rabbit cells ${ }^{6}$.

$\mathrm{CPE}$ and plaque appearance:

Fig. 3 (a) Typical small plaques having blurred edges produced by an HSV1 isolate 3 days after inoculation. (b) Large plaques and a few small (arrows) plaques were produced by HSV2 (strain UW-268) 3 days after inoculation. Edges are sharp and abrupt with both kinds of plaques. (c) Plaque-purified small plaque variants of HSV2 (UW-268) produces only small plaques. The cells were stained 3 days after inoculation. (d) Deformed plaques were obtained with the large membranous syncytium-producing HF strain (HSV1). (e) Mixed population of different size plaques were obtained with the $\mathrm{gC}^{-}$strain. (f) An enlarged picture of intermediate- and small-sized plaques of the $\mathrm{gC}^{-}$strain.

(a)

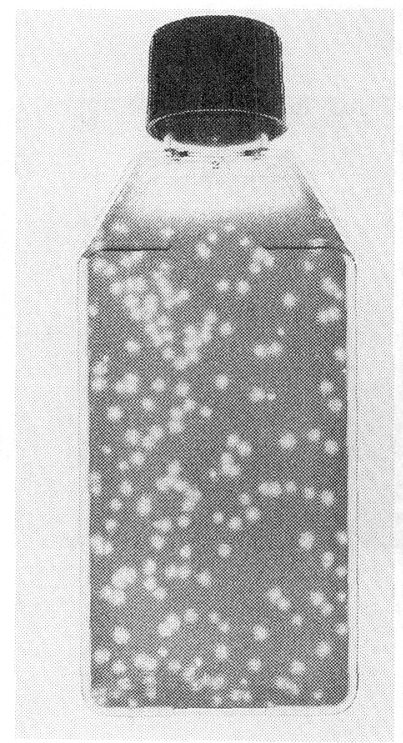

(B)

(d)

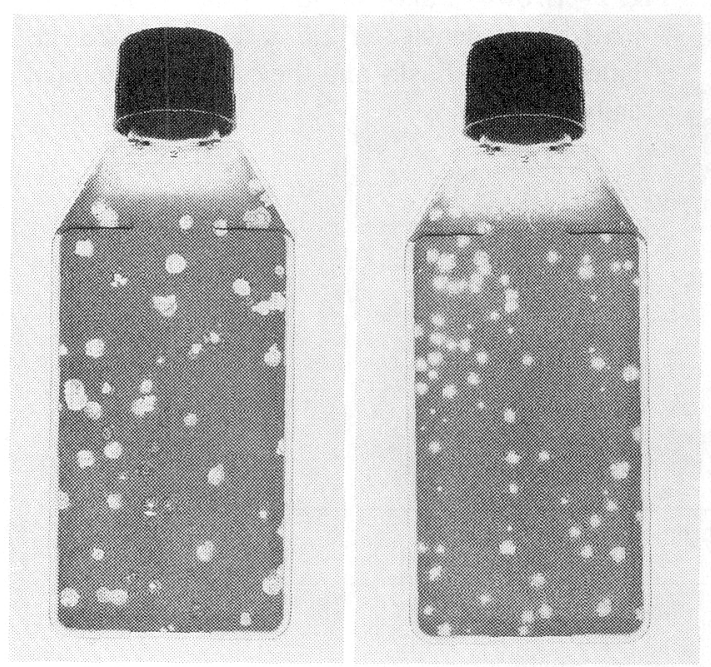

(A)

(b)

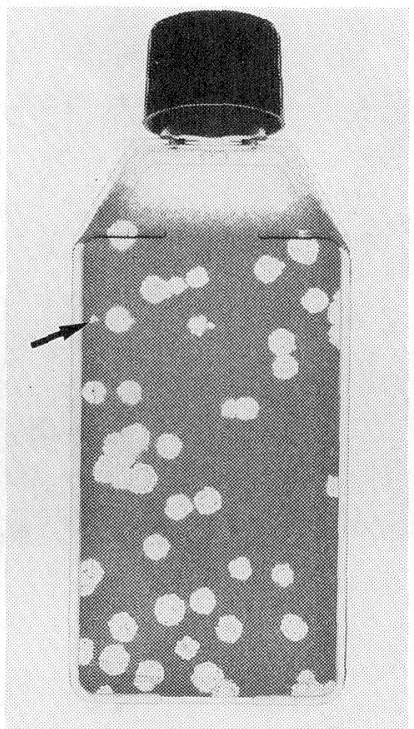

(c)

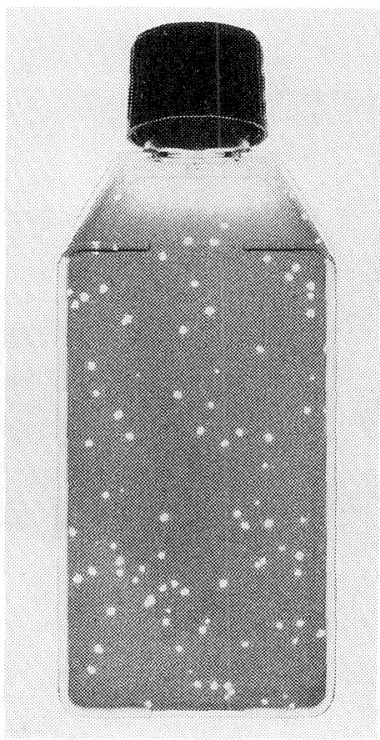

(C)

(f)

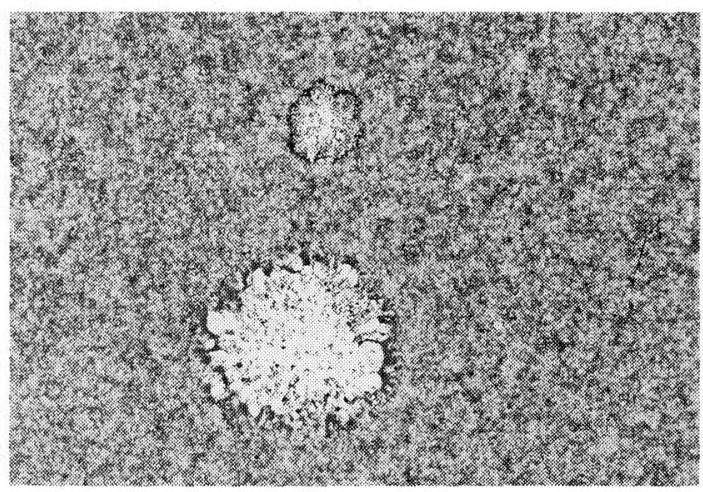


HSV1 strains produced CPE consisting of round cells plus syncytia (Fig. 1b), which produced small plaques (Fig. 3a). The mean diameter of these plaques was $1.29 \pm 0.37 \mathrm{~mm} 3$ days after inoculation on the 47th subculture of the RLE cells (Fig. 4). HSV2 strains produced two types of plaques. One was large (Fig. $3 \mathrm{~b}$ ) and the other was small (Fig. $3 \mathrm{~b}$ arrow and $3 \mathrm{c}$ ). The large ones were dominant in number with a ratio of about 20:1 to the small plaques. The mean diameter $(3.34 \pm 0.56 \mathrm{~mm})$ of the large ones 3 days after inoculation was about three times larger than that of the small ones $(0.97 \pm 0.31 \mathrm{~mm})$ with the same subcultures used for HSV1 (Fig. 4). The three mean diameters obtained here were almost the same as those obtained with other subcultures up to the 90th passage of the cells under similar experimental conditions (data not shown). Plaque sizes of HSV1 and of large and small plaques of HSV2 increased proportionaly through days 3, 5 and 7 after inoculation (Fig. 5). The CPE observed with the large plaques of HSV2 was characterized by a large membranous syncytium which was liable to lyse (Fig. 1c). The CPE with the small plaques of HSV2 consisted of small round cells with few syncytia which produced a bead-like arrangement around a clear area (Fig. 1d and 1e). The clones obtained from large plaques consistently produced large and small plaques; however the clones from small plaques produced only small plaques (Fig. 3c). This observation was confirmed with three consecutive plaque purification procedures with several large- and small-plaque clones (data not shown). This phenomenon is compatible with results of previous study utilizing the HeLa cell plaque assay system ${ }^{13)}$, although the proportion of the small plaque variants was larger than that of the large plaque variants in that study. Also, the small plaque variants reportedly produced syncytia in the HeLa cell system ${ }^{13)}$, contradictory to our results. The reference strain HF (HSV1)

Fig. 4 Mean plaque diameters of HSV1 and HSV2 obtained from different strains of each type of HSV with the 47th subculture of RLE cells. The cells were fixed and stained 3 days after inoculation. Top row: HSV1 strains; bottom row, HSV2 strains, strain UW-268 is at the far right.

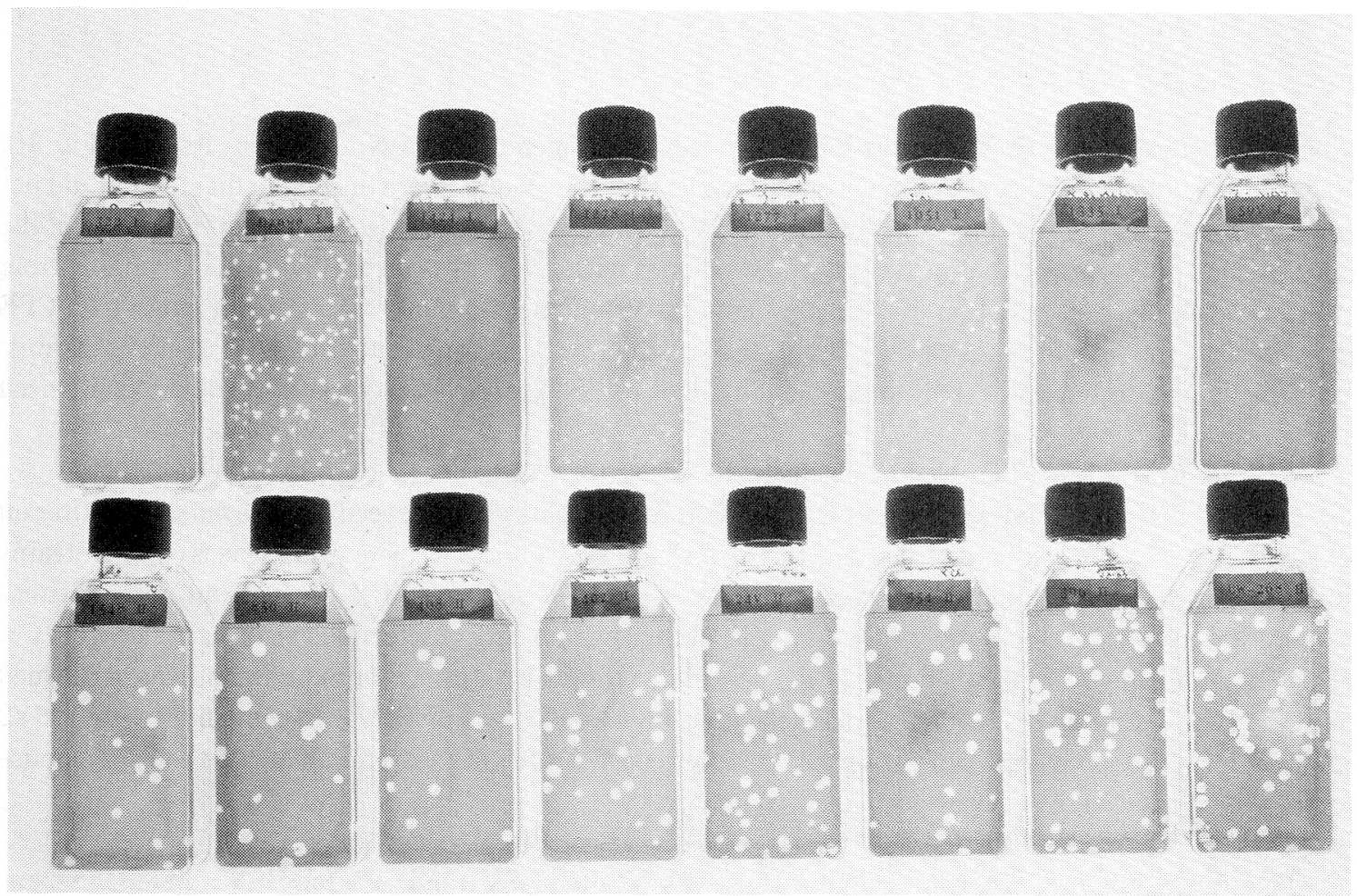


Fig. 5 Consistent size difference between the plaques of HSV1 and HSV2 on days 3, 5 and 7 after inoculation. Top row, HSV2; bottom row, HSV1.

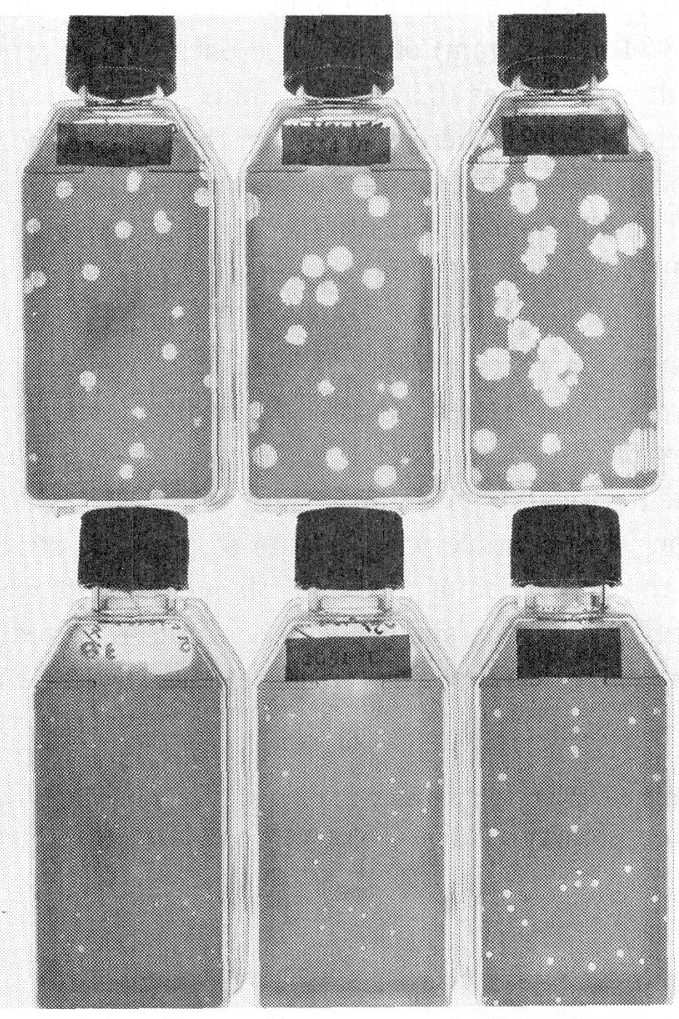

Fig. 6 One-step growth curves of HSV1 and HSV2 obtained with the 75th passage of RLE cells. Almost synchronyzed lag and logarithmic growth phases were seen with the two types of HSV but the maximum titer of HSV1 was about 90 times higher in that of HSV2. Open circle; HSV1, closed circle, HSV2.

One Step Growth Curves of HSV1 \& 2 with the RLE Cells

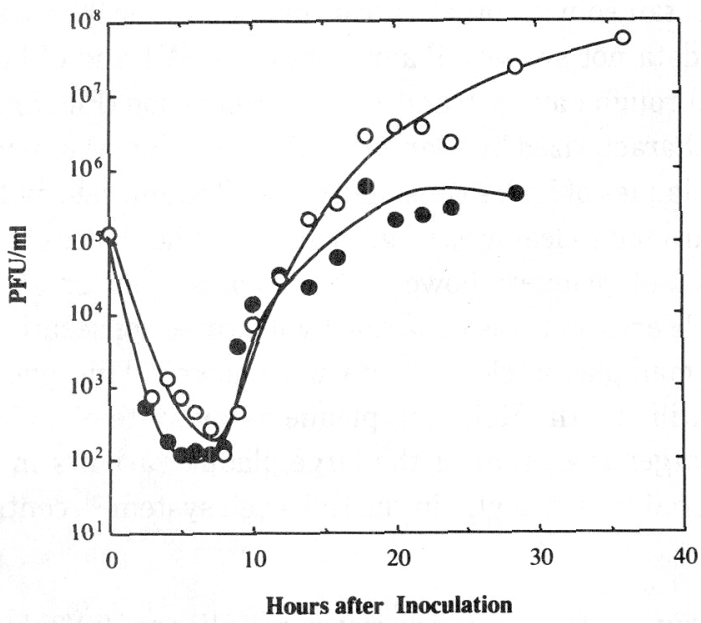

was an exception among HSV1 strains which formed a large membranous syncytium as its CPE (Fig. 1f). however, part or all of the syncytium was not lysed so that the plaques were uneven in diameter or did not appear with some syncytia (Fig. 3d). Three $\mathrm{gC}^{-} \mathrm{HSV} 1$ strains consecutively isolated from the cornea of the same patients with herpetic keratitis ${ }^{8}$ produced plaques with a variety of sizes (Fig. $3 \mathrm{e} \& 3 \mathrm{f}$ ) ranging from intermediate between HSV1 and 2 to pin point. The plaques except for pin point ones had CPE characterized by a membranous syncytium (Fig. 1g) which was not different from that of HSV2 strains. Round cells like those produced by small-plaque clones of HSV2 were characteristic of the pin point-sized plaques (Fig. 1h).

Growth characteristics of HSV1 and 2 on the RLE cells:

One of each type of HSV isolate was studied with regard to its growth speed and the maximum titer on RLE cells (Fig. 6). The eclipse period was 6 to $8 \mathrm{hr}$ for both HSV1 and 2. Exponential phases of both strains started $8 \mathrm{hr}$ after inoculation. The maximum titer of the HSV1 strain $\left(5.4 \times 10^{7} \mathrm{PFU} / \mathrm{ml}\right)$ was 92 times higher than that of the HSV2 strain $\left(5.9 \times 10^{5} \mathrm{PFU} / \mathrm{ml}\right)$. The numbers of infectious virus particles were 614 PFU per cell for the HSV1 strain and 6.7 PFU per cell for the HSV2 strain. The experiment was performed twice and gave similar result. The extremely high infectious titers of HSV1 as compaired with HSV2 obtained here are compatible with those previously reported with primary rabbit kidney cells ${ }^{2,16)}$, mouse embryo cells ${ }^{16\rangle}$ and human fibroblast ${ }^{16^{d}}$.

Sensitivity of RLE cells to HSV:

The average plating efficiency of Vero cells was $87 \%$ for HSV1 and $79 \%$ for HSV2 under the same 
Table 2

\begin{tabular}{cccc}
\hline & \multicolumn{3}{c}{ Titer (pfu/ml) } \\
\hline Type $^{\mathrm{a}}$ & Vero & RLE & $\begin{array}{c}\text { Efficiency of plating } \\
\text { on vero cells }(\%)^{\mathrm{b}} \\
\text { (Ave.) }\end{array}$ \\
\hline 1 & $2.0 \times 10^{7}$ & $2.8 \times 10^{7}$ & 71 \\
1 & $1.0 \times 10^{7}$ & $1.7 \times 10^{7}$ & 59 \\
1 & $3.0 \times 10^{7}$ & $2.7 \times 10^{7}$ & 111 \\
1 & $2.0 \times 10^{7}$ & $3.0 \times 10^{7}$ & 67 \\
1 & $5.0 \times 10^{6}$ & $4.0 \times 10^{6}$ & 125 \\
& & & $(87)$ \\
2 & $2.0 \times 10^{6}$ & $2.8 \times 10^{6}$ & 71 \\
2 & $1.1 \times 10^{6}$ & $1.7 \times 10^{6}$ & 65 \\
2 & $2.5 \times 10^{6}$ & $2.8 \times 10^{6}$ & 89 \\
2 & $2.5 \times 10^{6}$ & $2.7 \times 10^{6}$ & 92 \\
2 & $8.5 \times 10^{5}$ & $1.1 \times 10^{6}$ & 77 \\
& & & $(79)$ \\
\hline
\end{tabular}

a. Five isolates each of HSV1 \& 2 were randomly selected from our collection.

b. Plating efficiency was calculated by the formula : PFU obtained with Vero cells/PFU obtained with the RLE cells.

conditions (Table 2). Two HSV1 strains had a little higher titer with Vero cells than with RLE cells in this experiment; however titration was reliable with the RLE cells in terms of reproducibility. Difficulty in seeing plaques was often encountered with Vero cells.

Sensitivity of RLE cells to low infectious units of HSV:

The time for CPE to appear after inoculation of seven strains of HSV1 and six strains of HSV2 in Vero cell cultures which gave three to $10 \mathrm{PFU}$ with the RLE plaque assay was studied with RLE, HELF, RD and Vero cells. The cell cultures were prepared in glass tubes and maintained by rotation culture after virus inoculation. Several foci of CPE, shown in Fig. 1, appeared 16 to $21 \mathrm{hr}$ after inoculation in RLE cells with both types of HSV strains and the CPE covered more than $75 \%$ of the cells during the following $48 \mathrm{hr}$. In contrast, CPE started to appear in 40 to $48 \mathrm{hr}$ after inoculation in other cell lines and it took about $72 \mathrm{hr}$ for HEL and much longer for RD and Vero cells for the CPE to cover more than $75 \%$ of the cells after the CPE appeared.

Susceptibility of RLE cells to other viruses:

Although it was shown in our laboratory that rubella virus grows on RLE cells ${ }^{211}$, this cell line had little susceptibility to other viruses. The following viruses studied this time did not replicate in the RLE cells: polioviruses type 1,2 and 3; group B coxsackieviruses 1 to 6; echoviruses 9 and 30; rhinoviruses 1 and 14; VZV and CMV; influenzavirus $\mathrm{H} 1 \mathrm{~N} 1$ and parainfluenzavirus type 1 . However, adenovirus type 1 replicated and yielded $10^{5} \mathrm{TCID}_{50} / \mathrm{ml} 6$ days after inoculation. With a small number of infectious units of adenovirus type 1, CPE was not clear and there were no plaques.

Typing of HSV by plaque appearance:

Judgment of types was made in a single-blind manner by three observers 2 to 3 days after inoculation using two types of control strains in each experiment. For HSV1, one of the isolated strains identified as type 1 by the monoclonal antibody assay system and restriction endonuclease method was used as the control strain. This strain has the kind of CPE shown in Fig. 1a. For HSV2, the UW-268 strain was used as the control strain.

In order to judge the two types of HSV, a set of criteria for the plaque morphology and subcriteria for 
CPE were used. (A) Criterion for HSV1: Plaques produced by HSV1 strains are small and the mean diameter is close to that of the control strain in the same experiment. The edges of the plaques are rather blurred. (B) Criterion for HSV2: Most of the plaques produced by HSV2 strains are large and the mean diameter is close to that of the control strain in the same experiment. Small plaques having diameters $1 / 3$ to $1 / 5$ of the larger ones are also observed. The ratio of large to small plaques is roughly 20 to 1 . With both kinds of plaques, the edges are sharply demarcated.

The difference in appearance of CPE between the two types of HSV was taken as a subcriterion. CPE was observed just before the cells were fixed. (a) Subcriterion for HSV1: CPE observed with the plaques is characterized by round cells plus syncytia, as in Fig. 1b. (b) Subcriterion for HSV2: CPE observed with the large plaques is characterized by a large membranous syncytium most of which is lysed and a clear area is left, as seen in Fig. 1c. The subcriterion were taken as supportive standards for the criteria.

With all $40 \mathrm{HSV} 2$ strains including UW-268, the result of typing by the RLE plaque assay system was consistent with that of two other systems, Syva's Microtrak test and the restriction endonuclease digestion method. The small-plaque clones of HSV2 were verified as type 2 with Syva's monoclonal antibody assay system (data not shown). The only exception for the HSV strains studied was the reference strain $\mathrm{HF}$ because of its syncytium producing-nature. A little difficulty in judging was encountered with three $\mathrm{gC}^{-}$ strains, because some of the plaques were intermediate in size between HSV1 and 2. However, they were identified as HSV1, because the plaques had the same characteristics of appearance as the control HSV1 strain did and most of the plaques were smaller than those of the HSV2 control strain. The other 175 HSV1 isolates met the criterion for HSV1.

\section{Discussion}

RLE cells have prominent characteristics for HSV in which the plaques produced by HSV1 and 2 are distinguishable from one another by the appearances of their plaques. Plating efficiency of both HSV1 and HSV2 on the RLE monolayers was a little higher than that on Vero cells without any adaptation procedure which suggests that plaques are not representative of special clones in the virus preparations. There was about threefold difference in diameter between HSV1 and 2, which is sufficient to distinguish the two types of HSV. We believe that differentiation of HSV1 and 2 by plaque appearance using RLE cells is much easier than with RK cells ${ }^{15)}$. Furthermore, compared to primary cultures used for identification of HSV such as $\mathrm{CEF}^{2,12)}$, RK cells ${ }^{15,16)}$ and guinea pig embryo cells ${ }^{9)}$, laborious work will be eliminated if RLE cells are used to prepare culture for each experiment.

Since the large plaques of HSV2 strains were thought to be formed mainly by their unique CPE, in which extensive cell fusion and cell lysis occur, the difference in plaque size between the two types of HSV is considered to show the different biological characteristics of the two types rather than a mere technical phenomenon. Considering the two following observations, speed of replication of the viruses and the number of infectious particles per cell do not seem to be related to the plaque size: (1) The single-step growth curves of HSV1 and 2 showed an almost synchronized logarithmic growth phase, which means that the time required for a cycle of replication is nearly the same for HSV1 and 2 in RLE cells. (2) The number of infectious virus particles of the HSV1 strain produced in a single RLE cell was 92 times higher than that of the HSV2 strain (HSV1; $614 \mathrm{PFU} /$ cell, HSV2; $6.7 \mathrm{PFU} / \mathrm{cell}$ ), which is inversely related to the mean diameters of the plaques.

The use of different cell lines seems to have led to the discrepancy between the previous observation ${ }^{13)}$ and ours in terms of CPE and the proportion of small-plaques variants. Syncytium-producing clones in HSV2 preparations seem to make large plaques on RLE cells much more efficiently than on HeLa cells. Small-plaque clones of HSV2 were also seen in swab specimens obtained from herpetic lesions 
(unpublished data). Therefore, it is not only an in vitro but also an in vivo phenomenon for HSV2 to produce small-plaque clones.

Membranous syncytium-producing HSV1 strains, like the reference strain $\mathrm{HF}$ and the $\mathrm{gC}^{-}$strains studied here, produce relatively large plaques on RLE cells, which is considered to be essentially the same phenomenon as observed with HSV2. However, the nature of the membranous syncytium of HSV1 appears to be different from that of HSV2 in terms of liability to cell lysis, which could count as another biological marker to distinguish HSV1 from HSV2 in the RLE system. The HF strain also produces relatively large plaques on $\mathrm{CEF}^{22)}$, but the $\mathrm{gC}^{-}$dose not ${ }^{4)}$.

Mutants of $\mathrm{gC}^{-}$are recognized because of their syncytial or fusion-producing phenotype $\mathrm{e}^{5,17,24)}$ although the $\mathrm{gC}^{-}$and syn phenotypes are genetically separate $\mathrm{e}^{10,17)}$. Whether the clones of $\mathrm{gC}^{-}$strains from large plaques and small plaques behave like those of HSV2 or not remains to be studied.

Practically speaking, the following points are noteworthy with regard to RLE cells. (1) All the HSV1 and HSV2 isolates studied were differentiated from one another by the plaque appearance, which had agreed with the results of Syva's monoclonal antibody assay and restriction endonuclease analysis. (2) High sensitivity of the RLE cells to a very small infectious units of HSV and the rapidity of appearance of CPE should facilitate the laboratory diagnosis of HSV infection. (3) The reproducibility of the RLE plaque assay system is very reliable for the quantitation of HSV infectious particles. (4) A very narrow host range for various viruses was observed with RLE cells, so that, in the RLE culture system, the appearance of a $\mathrm{CPE}$ or plaques has meaning for presumptive diangosis of HSV infection in the clinical virology laboratory. (5) We have been using the same strain of RLE cells in the range of 40 to 90 passages for more than 12 years with occasional recovery of frozen cells so that the limitation of subculturing should be practically overcome. (6) Using overlay medium containing $0.8 \%$ methylcellulose rather than $1.0 \%$, the troublesome handling of a highly viscous methylcellulose solution can be eliminated without changing the plaque appearance. Therefore, we believe that RLE cells not only offer a novel plaque assay system for identifing HSV1 and 2, they also offer a very sensitive and stable system for quantitation of the viruses.

\section{Acknowledgements}

We thank Dr. Kazuhiko Shiina for his appropriate advice, and Atsuko Takahashi, Yuko Maekawa, and Minoru Fujiwara for their technical assistance. This work was partly supported by a grant from the Ministry of Education, Japan.

\section{References}

1) Anderson, C.A., August, M.J. \& Hsiung, G.D.: Pathogenicity of wild-type and tempearture-sensitive mutants of herpes simplex virus type 2 in guinea pigs. Infect. Immun. 30: 159-169, 1980.

2) Figueroa, M.E. \& Rawls, W.E.: Biological markers for differentiation of herpesvirus strains of oral and genital origin.J. Gen. Virol. 4: 259-267, 1969.

3) Hansen-Melander, E., Melander, Y. \& Olin, M.L.: Chromosome preparation by air drying at low temperature and giemsa banding procedure. Hereditas 76: 35-40.3, 1974.

4) Hidaka, Y., Sakuma, S., Kumano, Y., Minagawa, H. \& Mori, R.: Characterization of glycoprotein C-negative mutants of herpes simplex virus type 1 isolated from a patient with keratitis. Arch. Virol. 113: 195-207, 1990.

5) Holland, T.C., Homa, F.L., Marlin, S.D., Levine, M. \& Glorioso, J.: Herpes simplex virus type 1 glycoprotein $\mathrm{C}$-negative mutants exhibit multiple phenotypes. including secretion of truncated glycoproteins. J. Virol. 52: 566$574,1984$.

6) Hsu, T.C. \& Benirschke, K. (ed.): Oryctolagus cuniculus (Laboratory rabbit), vol. 1, Folio 8. In An atlas of mammalian chromosomes. Springer-Verlag, New York. 1967.

7) Kawana, T., Shinkai, K. \& Yoshino, K.: Typing of herpes simplex virus strains of genital and nongenital origins. Japan J. Microbiol. 18: 235-241, 1974.

8) Kumano, Y., Yamamoto, M., Inomata, H., Sakuma, S., Hidaka, Y., Minagawa, H. \& Mori, R.: Recurrent herpetic 
keratitis: Failure to detect herpes simplex virus infection using the Syva Micro Trak ${ }^{\mathrm{TM}}$ HSV1/HSV2 Direct Specimen Identification/Typing Test. 201: 169-173, 1990.

9) Landry, M.L., Mayo, D.R. \& Hsiung, G.D.: Comparison of guinea pig embryo cells, rabbit kidney cells, and human embryonic lung fibroblast cell strains for isolation of herpes simplex virus. J. Clin. Microbiol. 15: 842-847, 1982.

10) Lee, G.T.Y., Pogue-Geile, K.L., Pereira, L., Spear, P.G: Expression of herpes simplex virus glycoprotein C from a DNA fragment inserted into the thymidine kinase gene of this virus. Proc. Natl. Acad. Sci. USA 79: 6612-6616, 1982.

11) Lipson, S.M., Salo, RJ. \& Leonardi, G.P.: Evaluation of five monoclonal antibody-based kits or reagents for the identification and culture confirmation of herpes simplex virus. J. Clin. Microbiol. 29: 466-469, 1991.

12) Lowry, S.P.,Melnick, J.L. \& Rawls, W.E.: Investigation of plaque formation in chick embryo cells as a biological marker for distinguishing herpes virus type 2 from type 1. J. gen. Virol. 10: 1-9, 1971.

13) Munk, K. \& Ludwig, G.: Properties of plaque variants of herpes virus hominis strains of genital origin. Arch. ges. Virusforsh. 37: 308-315, 1972.

14) Nordlund, J.J., Anderson, C., Hsiung, G.D \& Tenser, R.B.: The use of temperature sensitivity and selective cell culture systems for differentiation of herpes simplex virus types 1 and 2 in clinical laboratory. Proc. Soc. Exp. Biol. Med. 155: 118-123, 1977.

15) Plummer, G., Goodherat, C.R., Miyagi, M. \& Skinner, G.R.B., Thouless, M.E. \& Wildy, P.: Herpes simplex viruses: discrimination of types and correlation between different characteristics. Virology 60: 206-216, 1974.

16) Plummer, G., Wamer, J.L., Phuangsab, A. \& Goodheart, C.R.: Type 1 and type 2 herpes simplex viruses: Serological and biological differences. J. Virol. 5: 51-59, 1970.

17) Ruyechan, W.T., Morse, L.S., Knipe, D.M. \& Roizman, B.: Molecular genetics of herpes simplex virus II. Mapping of the major glycoproteins and of the genetic loci specifying the social behavior of infected cells. J. Virol. 29: 677-697, 1979.

18) Sakaoka, H., Aomori, T., Saito, H., Sato, S., Kawana, R., Hazlett, D \& Fujinaga, K.: A comparative analysis by restriction endonucleases of herpes simplex virus type 1 isolated in Japan and Kenya. J. Inf. Dis. 153: 612-616, 1986.

19) Shapiro, A.L., siegel, I.M., Scharff, M.D. \& Robbins, E.: Characteristics of cultured lens epithelium. Invest. Ophthalmol. 8: 393-400, 1969.

20) Smith, J.W., Rodriguez, J.E. \& McKee, A.P.: Biological characteristics of cloned populations of herpes simplex virus types 1 and 2. Appl. Microbiol. 21: 350-357, 1971.

21) Tanifuji, Y.: Growth of rubella virus in cultured rabbit lens epithelium. Acta Soc. Ophthalmol. Japon. 75: 1679$1683,1971$.

22) Taniguchi, S. \& Yoshino. K.: An analysis of the plaque assay of herpes simplex virus in chick embryo monolayers. Arch. ges. Virusforsh. 14: 537-552, 1964.

23) Yang, J.P.S., Chiang, W., Gale, J.L. \& Chen, N.S.T.:A chick-embryo cell microtest for typing of herpesvirus hominis. Proc. Soc. Exp. Biol. Med. 148: 324-328, 1975.

24) Zezulak, K.M. \& Spear, P.G.: Mapping of the structural gene for the herpes simplex virus type 2 counterpart of herpes simplex virus type 1 glycoprotein $C$ and identification of a type 2 mutant which does not express this glycoprotein. J. Virol. 49: 741-747, 1984. 
家鬼水晶体上皮細胞を用いたプラーク法による単純へルペスウイルス

\section{1 型 2 型の実験室診断}

\begin{tabular}{llll}
\multicolumn{5}{c}{ 岩手医科大学医学部細菌学講座 } \\
佐藤 & 成大 & 金生 & 英雄 白井 淳一 \\
高橋 & 清実 & 川名 林治
\end{tabular}

(平成 5 年 1 月 11 日受付)

(平成 5 年 3 月 17 日受理)

\section{要旨}

我々は, 単純へルペスウイルス (herpes simplex virus ; HSV) 1 型と 2 型が，家鬼水晶体上皮細胞 (rabbit lens epithelial cells; RLE) 上で, 明瞭 に区別できる異なるサイズのプラークを形成する ことを見い出した。 $1 \%$ チルセルロースを含む 培養液を用いた条件下では, ウイルス接種後 3 日 目に打ける 1 型のプラークは小さく, 直径 $1.29 \pm$ $0.37 \mathrm{~mm}$ であった。 2 型は常に大きいプラークを 形成したが，同時におよそ20：1の頻度で小さい プラークの形成が認められた。接種後 3 日目では 大プラークは直径 $3.34 \pm 0.56 \mathrm{~mm}$ で小プラーク は直径 $0.97 \pm 0.31 \mathrm{~mm}$ であった。大プラークから 得られたクローンは大プラークと同時に常に小プ ラークを形成するクローンを上記の頻度で含んで いたが，小プラークから得られたクローンは小プ ラークのみを形成した. HSV1型による細胞変性 効果は球形細胞と多核細胞の混合であった。 HSV2型の大プラークを形成するクローンは細胞 変性効果として膜状の融合細胞を形成し，この融 合細胞は容易に溶解消失する性質を有していた。 これに対し小プラークを形成する HSV2型ク
ローンの細胞変性効果は球形細胞のみの集合で あった。これら HSV1型2型の RLE 細胞に対する 細胞変性効果の違いがプラークサイズの大小に反 映していると考えられた。 今回用いた糖蛋白 Cを 欠く 1 型株 $\left(\mathrm{gC}^{-}\right)$は 1 型と 2 型の中間サイズのプ ラークを形成し，また僅かながら小プラークを形 成するクローンが混在していた。それぞれの細胞 変性効果は 2 型に見られたものと類似していた。 RLE 細胞を用いたプラーク法による型識別の結 果と, シバ社のモノクローナル抗体による型識別 の結果は, HSV1型179株, HSV2型40株に扔いて, 実験室株である HF 株(RLE 細胞に沶いて膜状の 融合細胞を形成する）を例外として, 全て一致し た。むたこの結果は一部の株 (HSV 1型39株, HSV 2型 9 株) について行った制限酵素切断法の 結果とも矛盾しなかった。 以上のことから, RLE 細胞を用いたプラーク法は, 単純へルペスウイル 不感染症の実験室診断に拈いて有用であると考兄 られる。また, RLE 細胞は, HSV 1 型 2 型のいず れの型についても感受性が高く，かつ明瞭なプ ラークを形成することから，HSV の定量にも有 用な細胞であると考えられる。 